This is a truly wonderful work that adds the type of texture that is so often missing from historical studies. Of course, it can reasonably be argued that Fair-Schulz may be making too much of a limited sample to make his case. Yet, he argues forcefully to the importance of these individuals not merely as symbols but as significant political and social actors. Moreover, he freely admits the limitations of this first effort when he comments that further research "will produce a more rounded picture of the background, motivations, as well as patterns of thought and behavior of this intriguing group of people." (345) All the same, this is a remarkable book using innovative methodology, solid research expressed in clear prose on a little discussed but vitally important subject. One can only eagerly look forward to this fine scholar's future work.

William A. Pelz

Institute of Working Class History

François Maspero, Out of the Shadows; $A$ Life of Gerda Taro. Translated from the French by Geoffrey Strachan (London: Souvenir Press, 2008).

In this small book, François Maspero has restored Gerda Taro and her stunning photography to view in full light. As Maspero says, he has rescued her from the cruel fate of being always someone else's shadow; never her own. The figure that towered over Taro's life and work is Robert Capa. Probably the finest war photographer of the twentieth century, Capa was Taro's lover, compañero and partner in their commitment as photojournalists to document the horrors of the expanding Nazis movement and the heroism of those who stood against it.

Capa's oft-quoted dictum, that in war photography, if the image is no good the photographer is not in close enough, was one that Taro and Capa lived by. The extraordinary power of the photographic images they produced is proof of their principle: protagonist, photographer and viewer are immersed in the immediacy of the events captured in the picture. Their photographs are a lasting legacy to the Spanish civil war, instantly evoking that conflict. Taro's early pictures are optimistic and memorable: Catalan women undergoing military training on the beach outside Barcelona; the beaming militiawomen off to the Aragon front, in cap and uniform with Sam Browne belt and rifle as they farewell husbands and children. And probably the most famous photograph of the war is Capa's "The Falling Soldier", taken while he and Taro were filming on the Cordoba front in September 1936. The militiaman's head is flung back and the rifle extended away in outstretched arm, he has been caught in the frame at the very point of death. These are the images that signified Republican Spain then and have continued to do so ever since. But of course the other inevitable and terrible side of the Taro-Capa principle of war photography is that it required a 
limitless store of bravado and bravery from the person who keeps wielding the camera despite the danger of being immersed in the swirl of battle. The peril that underlay their principle is starkly evident in the deaths that separately overtook them; Taro first and then Capa.

Taro was killed in Spain in July 1937. Her tragic death not only brought an end to the vivid life of a vibrant young woman but it foreclosed the possibility of her future place at the centre of the new artistic movement that was modern photography. Shooting alone and on foot at the Brunette front, she was caught up in the chaos of the republican military retreat. Hitching a ride on the running board of a car, while continuing to film, she was sideswiped by an erratically driven republican tank and fell under the tank's moving tracks. She died that evening in a field hospital set up in The Escorial. Gerda Taro was twentyseven years of age; her short life was like a brilliant thread woven through many of the international events that marked European politics and culture in the 1930s. Capa was killed by a landmine in North Vietnam in 1954 as he filmed a French army unit in combat in the first stage of the Vietnam War.

Born Gerta Pohorylle in 1910 in Stuttgart, Taro was raised in the comfortable middle class. Her parents, secular Jews, had emigrated to Germany from Poland, eventually settling in Leipzig. Growing up in an environment that was liberal and leftist, it was no surprise that Gerta and her brothers were drawn to the anti-Nazi movement. In March 1933, she was arrested by the SA, accused of distributing anti-Nazi pamphlets. After a week in prison, and with the intercession of the Polish consul, Gerta was released and with the family's blessing headed to Paris where she moved into leftist German refugee circles. It was here in 1934 that she met the Hungarian photojournalist Endre Friedmann. He had arrived in Paris after two forced relocations, first from Budapest to Berlin, where he worked as photojournalist - his name made with his pictures of Trotsky - and then again to Paris after the Nazi take-over. The two fell in love but also shared energy and a political commitment to the anti-fascist cause. They were passionately interested in the new modernist medium of photography. With Friedmann's tutelage Gerta showed a great flair for photography. It was her idea that they change their names to make their work more saleable but, rather than gallicanising them, they adopted American-Hollywood -sounding names. Robert Capa resonates with Frank Capra the filmmaker and Gerda Taro and Greta Garbo have a curious affinity. From spring 1936 their work was distributed under the name "Capa and Taro".

Maspero points out the difficulty of separating reality from the myths that circulated around Taro after her death. She was appropriated by the French Communist Party, and one can easily see why it would be so. She was a fitting symbol: beautiful and high-spirited, but also talented and utterly committed to the defeat of the extreme Right. After her death, the body was brought back to Paris where an enormous funeral procession accompanied the coffin to Père 
Lachaise, her resting place close to that of the martyred communards. Although many of Capa's biographies have described Taro as a member of the Communist party, Maspero argues that her politics was not Stalinist Left but her personal charm and the obvious contribution of Capa's and her photography made her a valuable asset to the French left and to the Comintern front organizations that flourished in mid 1930s. Her work appeared in Regards, in $V u$ and on her first trip to Republican Spain she carried a press accreditation from Louis Aragon, the founding editor of the Popular Front newspaper Ce Soir. The great strength of Maspero's book is the dense context in which he locates Taro and Capa and their photographic output in the 1930s. The political groups that surrounded Taro in Spain and in Paris are laid out with clarity as are his reflections on the origins and development of the new medium of photojournalism and the weeklies and magazines in which her work and Capa's appeared.

François Maspero is a distinguished French publisher and writer whose own life was marked by many of the events that a decade earlier influenced the course of Taro's story. Maspero's parents were rounded up during the German occupation: his father a distinguished Sinologist died in Buchenwald; his mother survived Ravensbrük. As a young man he was part of the French Resistance and after the war became a noted publisher of postcolonial literature, specializing in writing about the Algerian war and the violence of French colonialism. Out of the Shadows is beautifully written, a tribute to the translator, and enriched by Maspero's insight about Taro and Capa and the political and artistic surroundings in which their lives were played out. For anyone interested in art, politics and culture in the 1930s, this is a must-read.

Judith Keene

University of Sydney

\section{Djurdja Bartlet, FashionEast: The Spectre that Haunted Socialism (Cambridge: The MIT Press, 2010).}

FashionEast is the first comprehensive history of fashion in the East- European socialist countries. This richly illustrated volume covers the whole life span of socialism from after the Russian Revolution until the collapse of the socialist system. Not only was the garment industry socialized but so too was fashion. It was a state affair, which was controlled by experts and state officials. Bartlett relies in her work mainly on written sources like fashion journals and women's magazines, but also uses other documents and official declarations. In addition, she has met and interviewed many former fashion specialists in these countries. The first hundred pages deal with Soviet fashion before the establishment of the socialist bloc after the Second World War. She takes up, for instance, the well-known con- 